\title{
Livsstil som tv-underholdning
}

\author{
Af Christa Lykke Christensen
}

Livsstilsprogrammer har siden slutningen af 1990'erne domineret programfladen i den tidlige prime time på de danske public service-kanaler DR og TV 2. Dermed er emner, som figurerer i bl.a. magasiner og ugeblade, massivt rykket ind på tv's sendeflade. Bolig, have, mad, ferie, krop og sundhed er indholdet i programmer, der både vil informere, give gode råd og underholde seerne. Artiklen fokuserer på underholdningsdimensionen $i$ tre kategorier af livsstilsprogrammer og undersøger elementer, der kan tænkes at fremme motivationen for at se dem. Her lægges vægten på hhv. vidensperspektivets kompetenceaspekt og livsstilsbegrebets imaginative muligheder i relation til drømmen om 'det gode liv' og ønsket om den forjættende forandring. Artiklen diskuterer endvidere, hvorledes public service-fjernsynet med disse livsstilsprogrammer har suppleret dets oplysende funktion med en opdaterende funktion, og hvordan dets tidligere kulturelt dannende funktion i kraft af disse programmers karakter af manual kan opfattes som en slags livsstilsguide i forhold til markedets forbrugsmuligheder.

\section{Livsstil - fra trykte til levende billeder}

Gennem de seneste ti år er der sket programmæssige ændringer af sendefladen på de danske public service-kanaler, DR og TV 2. Den tidlige prime time på ugens fire første hverdagsaftener er gradvist blevet udfyldt af programmer, der beskæftiger sig med livsstil eller livsstilsrelaterede emner. Bolig, have, mad, krop, hobby, rejser, kæledyr og forbrug udgør programindholdet, og formen kan spænde fra det instruktive gør-det-selv-program eller det kritiske forbrugermagasin, over programmer hvor makeover-aspektet udgør det centrale dramaturgiske omdrejningspunkt, til smagsfremstillende programmer, hvor livsstilsaspektet integreres med traditionelle underholdningselementer som konkurrencer og quizzer. Tidligere bestod denne del af sendefladen overvejende af komedieserier, dokumentar- og quizprogrammer, men livsstilsprogrammerne har siden 2000 været i stand til periodevis næsten at fortrænge disse fra fladen. Til gengæld er flere elementer fra dem blevet integreret i de mange former for programmer om livsstil, hvorfor disse ofte bliver kategoriseret som en hybridgenre under fællesbetegnelsen: faktuelle underholdningsprogrammer (Hill, 2005). I denne artikel skal vi dels se på, hvad der præger den 'faktualitet', der er på spil i disse programmer, dels overveje hvad det er, der gør disse programmer underholdende.

På samme måde som Charlotte Brunsdon taler om 'lifestyling' af britisk tv fra midten af 1990'erne med rod i en "general 'lifestyling' of late 20th-century British culture" (Brunsdon, 2003, p. 8), kan man tale om en tilsvarende "lifestyling" af dansk tv fra slutningen af 1990'erne. For britisk tv's vedkommende var der i høj grad tale om en såkaldt 'daytime-isering' af prime time, hvor programindhold, der tidligere var målrettet husmødre, pensionister og hobbyinteresserede i dagtimerne, flyttede ind i 
aftensendefladens prime time (Medhurst, 1999; Moseley, 2000). En sådan flytning var der ikke tale om for dansk tv's vedkommende, idet der ikke har været tradition for den slags daytime-tv i dansk fjernsyn.

På de danske tv-kanaler har der været tale om, at indhold, der figurerede, og stadig gør det, i magasiner og ugeblade, er rykket ind på tv, og her er blevet målrettet til hele befolkningen. Indholdet er forholdsvis populært, målt på seertal, idet mellem 500.000800.000 seere kigger med hver uge, og blandt de store seer-magneter harværet Hammerslag (1992-), Kender du typen? (1998-), Det' Leth (1998-2003), Hokus Krokus (1999-2008) og Helt solgt! (2001-04). For tv-stationerne udgør programmerne et 'guldæg', som Carlsen og Frandsen kalder dem (Carlsen \& Frandsen, 2005, p. 11), dels fordi de er forholdsvis billige at producere, dels fordi de, med de pæne seertal, programlægningsmæssigt repræsenterer et gunstigt potentiale i forhold til at få seere til kanalen resten af aftenen.

Sammenlignet med det trykte format, ugebladet og livsstilsmagasinet, giver tv-mediet mulighed for konstruktion af narrativer, hvor ideer kan følges over tid og ses praktiseret, ligesom det er muligt at iscenesætte indholdet som sociale handlinger med konsekvens for 'virkelige' personer. Det er argumentet her, at levendegørelsen og dramatiseringen af indholdet, med konkrete aktører i tid og rum, er med til at give programmerne underholdningsværdi. I forhold til det trykte format giver de levende billeder seeren mulighed for en medleven i de processer, der finder sted i programmerne. Denne medleven, formidlet over de forskellige æstetiske former, programmerne har, åbner for emotionelle tilknytnings- og/eller distanceringsmuligheder, hvilket i sig selv kan betragtes som en kvalitet ved seeroplevelsen.

\section{Forbedringskultur}

Livsstilsprogrammerne er ikke enestående mediefænomener, men del af hvad man kunne kalde en senmoderne forbedrings- eller makeover-kultur. Ikke blot tv's sendeflade, men også aviserne bugner af livsstilstillæg, stoffet er tilgængeligt i rigelige mængder på internettet, bl.a. som supplement til tv-programmerne, og antallet af livsstilsmagasiner til både kvinder og mænd er steget markant de sidste ti år. Hverdagslivet og kroppen gøres i disse medier til genstand for en refleksivitet og æstetisering, der imødekommer den moderne mediebrugers ønske om på den ene side at forstå sig som et særskilt individ, der gentagende arbejder på pleje, fornyelse og forbedring af sit selv og dertil gerne vil have inspiration, og som på den anden side, netop gennem disse massemedier, kan blive forsikret om, at selv-arbejdet foregår inden for alment accepterede normer, der gør den enkelte genkendelig for andre som netop et moderne selv, der forstår sig som en selektiv forbruger.

Tv-programmerne kan derfor betragtes som elektroniske versioner af et indhold, der figurerer samtidigt på flere medieplatforme, og som lægger vægt på hverdagslivet som "a site of perpetual 'renovation'” (Lewis, 2007, p. 2). De kan 'oversætte' modernitetens øgede individualisering, refleksivitet og smagsmæssige distinktion til adækvat praksis (Bourdieu, 1984; Giddens, 1991; Beck, 1992) og på den måde fungere som legitimering af denne 'perpetual renovation', hvilket i denne sammenhæng ikke mindst knytter sig til distingveret forbrug. Programmerne forsyner forbrugeren med handlingsorienterede argumenter for det positive og 'naturlige' i en øget individualisering og selv-refleksivitet og for et selvfølgeligt 'arbejde' på en øget smagsmæssig differentiering. Med tvprogrammernes massive tilstedeværelse på sendefladen markeres, at også tv-kanalerne ser det som deres opgave at være med til at stimulere disse tendenser, hvilket på den 
ene side imødekommer en seer, der set fra et motivationspsykologisk perspektiv føler sig underholdt ved at tilegne sig disse former for viden og kompetencer (Vorderer et al., 2006, p. 7), og som på den anden side bibringer programfladen et sigte, der giver oplysningsdimensionen i public service en mere instrumentel karakter end set tidligere på public service-kanalerne.

Ud fra et kønsmæssigt perspektiv er det interessant, at det trykte magasins indhold er blevet til elektroniske billeder. Hermed har, som Tania Lewis argumenterer for, programmerne været med til yderligere at forankre blikket på traditionelt kvindelige kompetence-, interesse- og omsorgsområder som et blik, der primært signalerer 'livsstil' (Lewis, 2007, p. 291). De har været med til at eksponere det reproduktive arbejde, der ligger i hjem, mad og krop, som æstetisk interessant ved at rette opmærksomheden mod dette arbejdes stilmæssige og smagsdifferentierende potentialer. Om der derfor nødvendigvis er tale om en femininisering af tv's sendeflade, kan diskuteres; snarere vil jeg argumentere for, at de områder, der, med baggrund i en traditionelt kvindelig livsverden, bliver gjort til genstand for tv-produktion, iscenesættes dramaturgisk på en måde, der primært optimerer dem som leg og nydelse, og at livsstilsblikket først og fremmest eksponerer hverdagslivet som afsæt for attraktiv legende virksomhed og som et sted for æstetiseret forbrug. Den hverdagsæstetiske imagination (Prokop, 1978, p. 97), der traditionelt har tilhørt den kvindelige reproduktionssfære som både konkret arbejde og som nydelsesfuldt dagdrømmeunivers, har derfor ikke blot undergået en massiv medieeksponering, hvor dagdrømmene iscenesættes som offentligt tilgængeligt skue. Den er også blevet genstand for en professionalisering, idet eksperter og fagfolk i stort tal befolker hovedparten af disse tv-programmer og med deres ekspertise forbinder æstetisk imagination med modellering af smag og identitet, hvorved der samtidig peges på den som et kommercielt potentiale.

På trods af denne professionalisering, eller måske netop som konsekvens af den, skal det i denne sammenhæng godtgøres, at tv-programmerne kan opleves som underholdende. Underholdningskvaliteten er både til stede i selve det forhold, at programmerne ansporer til videns- og kompetencetilegnelse og dermed kan opleves som en udfordring (Vorderer et al., op.cit.), og i den måde, hvorpå programmerne, med Richard Dyers formulering, tegner konturerne af en "utopisk sensibilitet" (Dyer, 1992, p. 24). Denne udkrystalliserer sig primært i måden, hvorpå programmerne iscenesætter viden og arbejde som synonymt med leg, og derved kan bibringe seeren en lystfyldt 'energi' og fornemmelse af individuel styrkelse. Således kan det professionelle element i sin æstetisk iscenesatte form både give plads til seerens fornemmelse af bemestring og overskud.

\section{Nærhedsperspektivet}

Trods genremæssige forskelligheder, som vi senere skal vende tilbage til, er det et fællestræk for livsstilsprogrammerne, at det er de hverdagslige gøremål, der tilhører folks fritid, som står i fokus. Fraværende er f.eks. den politiske offentlighed og arbejdslivets krav, ligesom økonomiske og sociale problemer er det. Seerne stifter først og fremmest bekendtskab med en hverdagsvirkelighed, hvor der er tid til at dagdrømme ud fra ønsket om øget velvære, og hvor drømmene enten bliver realiseret for øjnene af seerne, eller der gives konkrete råd til, hvordan seerne kan forbedre deres situation. Alt sammen foregår det i rum præget af velvilje, hvor den gensidige forståelse er gennemgående, med dialog og samtaler, der anerkender, at de 'små' og nære ting har stor betydning. Således prioriteres konsekvent et nærhedsperspektiv, idet seerne f.eks. får adgang til såkaldt almindelige menneskers hjem og her får indblik i tanker og overvejelser over 'små', hverdagslige ting 
og beslutninger. Der males og tapetseres i de private stuer, der laves ny og spændende mad i diverse køkkener, der anlægges rosenbede, plantes buske og gives håndværksmæssige fif og gode tips til billige indkøb. Men uanset hvor meget der arbejdes, foregår det i en sfære af frivillighed. Karakteristisk for det, der laves, er, at det aldrig er tvingende nødvendige ting. At give sig i kast med dem alligevel repræsenterer derfor et overskud, noget ekstra, og det er muligvis dette 'ekstra', der, som en utopisk mulighed midt i det hverdagslige, for mange seere gør programmerne værd at se.

Perspektivet er således sat på livsverdenens nærhed. For seeren åbnes en 'virkelighed' at synke ind i, hvor den sanselige og æstetiske glæde ved de små og overflødige ting bliver sat i centrum og værdsat; hvor sociale handlinger foregår i en positiv stemning og konkret arbejde virker overkommeligt og udføres af navngivne personer, og hvor de pligter, der opereres med, er af den særlige karakter, at de dybest set slet ikke er forpligtende, da de i mere abstrakt forstand er møntet på selve den etiske forpligtelse på 'det gode liv'. Programmernes præmis er, at projekter, som konkrete mennesker sætter sig for at gennemføre, faktisk lykkes, og at det netop lykkes, fordi folk er i besiddelse af en vilje til at tage de nære ting alvorligt. Selv om der således er megen fokus på konkrete arbejdsog læreprocesser - der graves have, males vægge, hakkes grønsager - så fremstilles dette trivielt hverdagslige arbejde ikke desto mindre som en leg og en æstetisk nydelse. Dette gøres på flere måder: dels æstetisk og visuelt, f.eks. ofte ved brug af zoom på arbejdsprocesser, detaljer, teksturer og farver, som er med til både at formidle en taktil fornemmelse for og at 'emotionalisere' tingenes verden (Christensen, 2008); dels ved hjælp af eksperter og fagfolk, der både har hænderne skruet rigtigt på og derfor på nærmest legende vis formidler deres værdifulde viden; og endelig på det diskursive plan, hvor forestillingerne om det nære og hverdagslige forbinder sig entydigt positivt til betragtningen af hverdagen som et livsstilsprojekt. Uanset hvor meget der arbejdes på livsstilen, postulerer programmerne, at der altid er tale om et overskud af tid og energi - både som middel og mål. Overfor en sådan iscenesat hverdag, hvor trivialiteten og de sure pligter er forduftet, vil den afslappende nydelse derfor være en adækvat seermæssig position.

Nærhedsperspektivet er uden tvivl centralt for disse programmers underholdende kvaliteter, men kan ikke stå alene i en programkarakteristik. Ganske vist kommer seeren tæt på mere private dele af folks tilværelse ved at høre dem reflektere over begrundede valg af hus, tøj og mad, men disse hverdagslige rum og refleksioner eksponeres samtidig for et livsstilsblik, der tydeligst markerer sig i form af den professionelle know-how, som diverse eksperter er leveringsdygtige i, og som tilretter det hjemlige miljø i bred forstand i forhold til det omgivende samfunds normer for design, mad- og kropskultur (se Christensen, 2007). Ligeledes er programmerne indirekte rammesat af en generel markedsorientering, der primært ytrer sig i det forhold, at programdeltagere og seere med selvfølgelighed positioneres som forbrugere. Det illustreres bl.a. ved, at der tales en hel del om priser i mange programmer, og endvidere ved, at priser på f.eks. udført håndværksarbejde, på anskaffede ting og på boliger angives eksplicit på tv-skærmen som regulær forbrugeroplysning til seeren, ligesom sammenhængen mellem sponsor og tvprogram er åbenlys. Den følelse af bemestring, seerne indadtil 'leger' sig til i nydelsen af programmerne, kan således også have en mere udadvendt retning, idet programmerne kan fungere som guide i forhold til seeren som forbruger, der skal serviceres med ideer til ajourføring og fornyelse af livsstilen. 


\section{Genrehybrider}

Genremæssigt er livsstilsprogrammer vanskelige at definere præcist, både fordi sendefladen består af mange og forskellige programtyper, og fordi det enkelte program i sig selv er en hybrid, som det er vanskeligt at sætte på en velafgrænset genreformel. Nogle vægter det informative aspekt højt, f.eks. forbrugermagasiner som Rene ord for pengene (1994-2003), Kontant (2003-) og Ha' det godt (2007-), mens andre programmer lægger mere vægt på traditionelle underholdningselementer, som f.eks. Kender du typen? og Hammerslag, hvis dramaturgiske fremdrift er baseret på gættekonkurrencer mellem eksperter og fagfolk. Livsstil på tv kan derfor ikke kategoriseres som én bestemt genre. Programmerne knytter hver især forskellige kontrakter med seeren, udfylder forskellige funktioner og 'gør' derfor noget forskelligt i forhold til seeren.

At genredefinitionen er vanskelig i forhold til denne type programmer, fremgår også af forskningslitteraturen på området. Annette Hill forsøger sig med en bestemmelse (Hill, 2005; Hill, 2007) og redegør for, hvordan programmer, der tematiserer livsstil inden for en faktuel ramme, er blevet kaldt flere forskellige ting, siden de for alvor i begyndelsen af 1990'erne begyndte at dukke op på britisk tv, bl.a. leisure, infotainment, educational, lifestyle, reality programmes m.fl. (Hill, 2005, p. 41-56). Mangfoldigheden kan ses som udtryk for den forvirring, der har knyttet sig til de mange fakta-eksperimenter i 1990'erne, hvor der med afsæt i de traditionelle dokumentarformer blev taget livtag med 'virkeligheden' på nye og provokerende måder. Hill definerer livsstilsprogrammer på denne måde: "There are two types of lifestyle: instructional and makeover programmes. Instructional programmes offer straightforward advice and are close to consumer programmes. Makeover programmes focus on the transformation of something, and are closer to constructed popular factual" (Hill, 2007, p. 51). Her skelnes mellem instruktive og makeover-programmer. Hill kategoriserer makeover-programmer som liggende tættere på 'constructed popular factual'-programmer, hvis afgørende træk ifølge hende er, "that someone is removed from their normal environment and placed in a new one, and any change that takes place would not have occurred without the proactive and deliberative intervention of the production company" (ibid., p. 49). I forhold til en sådan definition er det vigtigt at understrege, at for de danske makeover-programmers vedkommende gælder, at de stort set altid foregår i hjemmet hos den, der eksempelvis får istandsat et køkken (Helt solgt!), får en ny have (Hokus Krokus, Ønskehaven (2008)), får ryddet grundigt op (Ryd op i dit liv (2005)) eller gjort ordentligt rent (Rent Hjem (2004-05)). Det fratager dem naturligvis ikke elementet af 'konstruerethed', men det er et vilkår, de som så mange andre fakta-programmer er underlagt.

Hills kategorisering tager imidlertid ikke højde for en særlig programkategori, som i hvert fald i Danmark har gjort sig gældende. Udover de programmer, der yder konkret vejledning, og makeover-programmerne findes en tredje kategori af programmer, hvor 'livsstil' hverken er noget, der direkte vejledes til med konkrete tips og nyttige råd, eller hvor en bolig eller have er genstand for en makeover, men hvor derimod forskellige former for livsstil blot præsenteres og gøres til genstand for et nærmere nysgerrigt kig. I f.eks. programserien Kender du typen? kommer seeren på besøg hos en ofte semikendt person, hvor der guides rundt i dennes private hjem med to livsstilseksperter, der udfolder deres viden om stil og smag i forhold til det pågældende hjem og dets beboer. I serier som Hammerslag og Liebhaverne præsenteres seeren ligeledes for private hjem, hvor præsentationen sker fra det bestemte perspektiv, at enhver bolig altid er udtryk for eller rummer potentialer for bestemte former for smag og livsstil. Sådanne programmer 
kan derfor betegnes som smagsfremstillende programmer. I sådanne programmer tages seerens viden om livsstil og parathed i forhold til stilisering af eget liv for givet, hvorfor både seerens behov for viden og leg med utopiske forestillinger om ikke kun en ny livsstil, men en ny tilværelse kan blive stimuleret.

Til genremæssigt at fange denne programkategori er Carlsen og Frandsens opdeling indledningsvis mere anvendelig, idet den skelner mellem henholdsvis nytteprogrammer og livsstilsprogrammer (Carlsen \& Frandsen, 2005, p. 12), hvorunder programmer med forskelligt tematisk indhold (bolig, krop, mad osv.) dernæst placeres. Denne opdeling er gunstig, eftersom den peger på (i hvert fald) to kommunikationsstrategier og seeropfattelser: på den ene side den oplysningsprægede, undertiden didaktisk orienterede seer-henvendelse, hvor seeren forventes at blive informeret og lære noget konkret af programmet, og hvor programværten ofte står stærkt profileret i både performance og holdninger til det pågældende tema. Det gælder f.eks. forbrugerprogramserien Rabatten (2002-), den instruktive handyman-serie Det' Leth samt magasinet Lægens bord (1997-), hvor henholdsvis Henrik Dahl, Flemming Leth og Peter Qvortrup Geisling i høj grad har været og er indbegrebet af programmerne.

I den anden ende af skalaen har vi en henvendelsesform, der i højere grad opererer med en seer, der går efter selve oplevelsesværdien ved at stifte bekendtskab med forskellige typer af boligindretning, mad, rejser, ting og fritidsaktiviteter, og som i mindre grad går efter de konkrete tips og råd. Værten er typisk mindre skarpt profileret og fungerer snarere som en med-seer eller "en mediator for kontakt mellem programmets deltagere og mellem program og seer" (ibid., p. 18). Eksempler kan være Kender du typen? og Liebhaverne. Her gøres mere plads til seerens formodede fantasi og æstetiske vurderingsevne, hvorved der snarere peges på selve potentialet for, at der kan læres, og at livet kan blive bedre, frem for hvad en vært eller ekspert måtte mene, at der bør læres, eller hvordan der $b ø r$ leves ud fra anviste måder. Man kunne, med Eco, sige, at i smagsfremstillende programmer forekommer 'teksten' mere åben end i nytteprogrammerne, der baserer sig på flere konkluderende og instruktive udsagn og resultater. De opererer i princippet med en åben struktur, hvor det er muligheden for forandring, der er vigtig, frem for selve resultatet af forandringen. De smagsfremstillende programmer appellerer derfor i en mere abstrakt forstand end nytteprogrammerne til det Dyer'ske potentiale for seerens fornemmelse af en 'utopisk' dimension.

Denne tredeling i programkategorier er pragmatisk til analytisk brug, idet den afdækker, at der er tale om forskellige afsenderintentioner og modtagerpositioneringer, og i modsætning til Hills genredefinition gør den det muligt at placere makeover-programmet som en mellemkategori mellem det nytteorienterede og det smagsfremstillende program, hvor det selvfølgelig skal understreges, at nytteprogrammer også beskæftiger sig med smag og livsstil, og at seerne omvendt også kan drage nytte af at se smagsfremstillende programmer, om end i en mindre konkret forstand. Ser man samtidig disse tre kategorier i et historisk perspektiv, vil der for den danske programudvikling være tale om, at nytteprogramkategorien var den første, udsprunget af en lang tradition på DR for oplysningsprægede faktaprogrammer; dernæst dukkede makeover eller makeover-lignende programtyper op, og sidst kom de smagsfremstillende programmer til - en udvikling, som dog ikke er entydig, men alligevel tegner en tendens. De tre programkategorier kan selvsagt ikke afgrænses entydigt fra hinanden. De flydende grænser imellem dem er måske endda en fordel, når man ser på den relativt store seerattraktion, disse programmer udgør. Muligvis er seerne tilfredse med, at seerkontrakten ofte er 
flertydig, da det åbner flere indgange for en imaginativ og emotionel anknytning til de enkelte programmer og dermed også forøger deres underholdende potentiale.

\section{Den tv-medierede smag}

Programmer om livsstil er ifølge John Ellis populære, fordi de giver seerne et indblik i andre menneskers hverdagsliv (Ellis, 2000), og her taler han bredt om alle programkategorier. Dog mener han ikke, at programmerne tilgodeser en traditionel voyeurisme, men snarere giver seeren mulighed for en mere udvidet betragtning af selve det hverdagsliges og 'det almindelige livs' beskaffenhed, og at programmerne som sådan spiller en vigtig rolle for tv-stationerne i forhold til at opretholde tv's nærhed til det liv, deres seere er optaget af, når de ikke ser fjernsyn:

They sharpen awareness of all the subtle social distinctions that are conveyed by clothes, speech and lifestyle, and at the same time humanize them. They allow a small glimpse behind the designer labels and the style allegiances of public street culture, to see a more private side of consumerism, where commodities are infused with personal associations (Ellis, 2000, p. 112).

Tv-programmer om livsstil er altså, ifølge Ellis, kendetegnet ved ikke blot at skærpe opmærksomheden på betydningen af sociale distinktioner i det hverdagslige mikrokosmos, men også ved at menneskeliggøre disse ved at fremvise en mere privat side af forbruget, hvor seeren får indblik i, hvordan 'de andre' praktiserer deres forbrug. Disse ting kunne en seer i princippet også finde ud af ved at gå en tur på strøget, hvorfor man må skærpe Ellis' iagttagelser derhen, at den medierede virkelighed har nogle særlige kvaliteter, som den ikke-medierede ikke har, og som tilsyneladende tiltrækker seere.

For nytteprogrammet kunne dette forhold dreje sig om, at seeren får udstukket konkrete anvisninger på, hvordan et problem effektivt kan løses, hvorved seeren kan slippe for at sætte sig ind i et kompliceret område. Attraktionen kunne endvidere være den bekræftelse, der ligger i selve det forhold, at der altid er en løsning på et givet problem, hvilket kan opleves som behageligt. Og det kan opleves som udfordrende, at der konkurreres på forskellig vis om, hvilken løsning der er mest optimal ud fra givne parametre. Desuden at der altid er en vinder-løsning, som seeren efterfølgende kan justere sine egne forventninger og viden i forhold til.

For makeover-programmet kunne kvaliteten bestå i selve forvandlingsaspektet, nemlig hvordan det ved hurtige beslutninger, velvalgte og aldrig forkerte hjælpemidler samt velvillig og glad arbejdskraft på nul komma fem altid kan lade sig gøre at forvandle en kedelig før-situation til en absolut bedre efter-situation. I disse programmer bliver de medvirkendes emotionelle tilstande tilmed inddraget, således at seeren får et glimt af den store betydning, som en sådan forvandling kan have for det enkelte menneske (Jerslev, 2008). Det afgørende øjeblik, hvor f.eks. den nye terrasse afsløres i Hokus Krokus, kan således give anledning til såvel de medvirkendes som seernes sentimentale tårer over både det overraskende og 'fantastiske' resultat og over den betænksomhed og sympati, andre har tilkendegivet over for den pågældende haveejer ved hjælp af denne forvandlings-gave. Som i den ikke-medierede virkelighed oplever seeren, hvordan tingenes overfladiske verden og de sociale relationer kan være dybt forbundne - men tv-medieringen sørger, i kraft af sine æstetisk 'forstørrede' og indrammede tableauer, for seerens direkte adgang 
til disse situationer, hvorfor der åbnes for en mere effektiv emotionel respons end i den 'virkelige' virkelighed.

For det smagsfremstillende programs vedkommende drejer det sig ikke nødvendigvis om seere, der interesserer sig for fornuftige løsningsforslag, der kan gøre hverdagen lettere (og billigere), ej heller ønskes oplevelser af, hvor hurtigt man kan ændre sit liv, for dybest set er denne seer allerede i besiddelse af både personlig stil og livsstil, og interessen er snarere drevet af ønsket om at holde sig opdateret i forhold til nye stilmæssige tendenser ud fra den erfaring, at livsstil altid handler om at raffinere og kultivere yderligere. Sådanne programmer opererer med den type mediebruger, som André Jansson karakteriserer som eksponent for "en imaginativ hedonisme" (Jansson, 2002a, p. 430), dvs. en seer, der er optaget af symbolske dimensioner og værdier ved oplevelser og varer, og hvor det i højere grad er den æstetiske, åndelige og emotionelle stimulation, frem for den kropsligtsanselige, der efterspørges. Den imaginative hedonist er en dagdrømmer, der håber at få indfriet nogle af de længsler, som mediebilleder af varer, boliger, hjemlige aktiviteter og rejsemål skaber. Drivkraften ligger således i selve den stimulans, de medieskabte fantasier om muligheden for nye oplevelser er med til at fremme.

\section{Hjemmet som scene}

Selv om Ellis fremhæver levendegørelsen af det private konsum som disse programmers fascinationskraft, fanger han imidlertid ikke, at det blik på hverdagen, som artikuleres, specielt for makeover- og de smagsfremstillende programmernes vedkommende, er et livsstils-blik. Derfor kan både omfanget og karakteren af det indblik i 'det daglige livs beskaffenhed', som Ellis mener, at disse programmer giver, problematiseres. For der er som regel tydelige grænser for dette indblik i andres praksis med stil og forbrug. Ganske vist kommer seeren tæt på de medvirkende ved at komme på besøg i deres private hjem, men programmerne handler sjældent direkte om de pågældende personer, om deres sociale adfærd og væremåde på nogen dybere og indsigtsfuld måde - og slet ikke om deres intime familieforhold og kærlighedsliv. Der er med Meyrowitz (Meyrowitz, 1986) ikke tale om et kig back stage. Snarere befinder vi os i det mere neutrale middle region, hvor der, selv om de medvirkende fremviser deres hjem med de mangler, det tilsyneladende måtte besidde, gøres meget for at oppebære et respektabelt ansigt udadtil hos de medvirkende. Kameraet har ikke til hensigt at afsløre uheldige eller pinlige detaljer i de medvirkendes bolig eller tilværelse - bortset selvfølgelig fra de programmer, der som del af konceptet fokuserer på mere grænseoverskridende situationer, f.eks. programserien Rent Hjem, der eksplicit stiller skarpt på snavs og skidt i folks hjem. Her kommer den pinlige afsløring dog ikke overraskende bag på seeren, idet skidtets tilstedeværelse og bortfjernelse er seriens grundidé. Seeren ved fra begyndelsen, at der her vil forekomme opsigtsvækkende billeder, men overbevises af programmet om, at de fremviser en undtagelsessituation, og at de deltagende personer gør, hvad de kan for at rette op på denne 'skade' - som var den en kriminel handling, man som seer har ret til at få begrundet. Programserier som Rent Hjem har dog hidtil været relativt få på de danske public service-kanaler.

Ansigtstabet, som er populært tv-indhold i diverse reality-formater, optræder stadig forholdsvis sjældent i de danske livsstilsprogrammer, om end udviklingen muligvis vil gå den vej. Der er derfor ikke blot tale om en ganske behagelig atmosfære i de danske programmer, hvor brud og konflikter sjældent tematiseres. Endvidere holder især makeover-programmerne sig stort set inden for en horisont, der udgøres af det private hjem eller af omgivelser, der konnoterer hjemlighed på forskellig vis, hvilket i sammenhængen 
udelukkende konnoterer hygge og familiesammenhold. Dog er det vældigt beskårede dele af folks private hjem, seeren stifter bekendtskab med, eksempelvis entreen, der skal friskes op i Helt solgt!, eller stuen, som naboerne i Roomservice (2000-05) skal renovere. Hjemmets øvrige rum figurerer sjældent, ligesom heller ikke børn og kæledyr er til stede, førend eventuelt til sidst i programmet, hvor de skal bidrage til beundring af det færdige resultat. Deborah Philips siger om disse 'makeover-hjem', at de "exist without a context" og at "The television domestic interior is presented as if it were an [...] atomized space" (Philips, 2005, p. 224-5), hvilket i sig selv kan være med til at stimulere seerens egen evne til at kontekstualisere det sete. Den fraværende kontekst kan også være tilfældet i nytteog smagsfremstillende programmer (f.eks. Kender du typen?), men tendensen går dog i retning af inddragelse af en bredere kontekst. Eksempelvis får vi, når Camilla Plum skal bage boller, ikke kun et kig ind i hendes køkken, men også i hendes gård og butik (Boller af stål (2008)). Claus Meyer tilbereder sin mad udendørs i mange egne af Danmark (Smag på Danmark (2007)), ligesom seere af Feinschmecker (2008) tages med på auktioner og markeder for at finde det helt rigtige design. Viden om stilens og smagens udfoldelsesrum og referencerammer er dermed centrale elementer i at kunne imødekomme seeren og peger på, at der kan være stor forskel på den seer, der ønsker at blive underholdt ved hjælp af hurtige og smarte forandringer, og den seer, der gerne vil fordybe sig i de processuelle samt videns- og smagskulturelle aspekter forbundet med artikulation af livsstil.

\section{Behagelige seeroplevelser}

Når pinlige situationer i de danske livsstilsprogrammer undgås, betyder det for alle tre programkategoriers vedkommende, at dramatiske elementer, der angår menneskelige relationer, underbetones. Det centrale indhold er ikke, hvordan personerne er psykologisk og socialt, men at de handler - og dét på en bestemt måde, nemlig at de med gå-på-mod går i clinch med tingene og igennem praktiske aktiviteter skaber en ny og bedre situation for sig selv og helst også for de 'nære' andre. Der fokuseres på navngivne personers (seeren er på fornavn med alle) konkrete drømme og på deres beslutsomme handlinger i forhold hertil. Udfra et kropsfænomenologisk perspektiv kunne man sige, at programmerne hermed øger seerens følelsesmæssige adgang til det kropslige 'kunnen'-aspekt. Ved at stimulere kroppens disponerethed for 'jeg kan' (frem for 'jeg tænker') (Thøgersen, 2004, p. 116) kan programmerne med deres fremstilling af meningsfulde relationer mellem krop, handling og genstand være med til at bringe seeren i en basalt set behagelig, opstemt tilstand, der kan føles underholdende. Deltagerne forholder sig altid konstruktivt til løsning af problemer; de bliver aldrig sure, når de eksempelvis taber i diverse konkurrencer og quizzer, ligesom det også er sjældent, at den endelige afsløring for ejeren af f.eks. et renoveret køkken resulterer i negative emotionelle udladninger. Programmerne bærer i udstrakt grad præg af en selskabelig omgangsform, hvor samværet deltagerne imellem er det primære formål (Hjarvard, 2003, p. 14), hvor konfliktniveauet derfor altid er håndterbart, og hvor der aldrig tabes ansigt. Hverdagen får dermed mere karakter af leg og sjov end af pligt.

At seerne kun får begrænset adgang til de medvirkendes 'indre' og private liv, betyder på den anden side ikke, at der ikke reflekteres over tilværelsens forhold og problemer. Men seeren får udelukkende indblik i problemer på et bekymringsniveau, hvor der inden for programmernes afstukne rammer altid anes en løsning på problemet. Det er de medvirkendes strategier og handlinger i forhold til tingenes og den praktiske verden, der bliver det centrale: 
I modsætning til fx realityprogrammer, hvor kampen mellem personerne skal være aggressiv, så programmernes fascinationskraft består i seernes holden med eller irritation over deltagerne, så skal livsstilsprogrammets seere ikke reagere på personerne, men på deres valg af møbler, farver, fliser osv. altså sammenlagt deres livsstil. (Carlsen \& Frandsen, 2005, p. 21)

I nytteprogrammet får seeren bevis for funktionaliteten af diverse råd, bageteknikker og beskæringsmetoder; i makeover-programmet fokuseres ligeledes på teknikker og metoder, men med et mere effektivt fokus på forholdet mellem arbejdsindsats og resultat i kraft af før- og efter-sekvenser, ligesom der ofte tilknyttes et personligt emotionelt minidrama; endelig lægger det smagsfremstillende program op til stimulation af seerens æstetiske fornemmelse for og vurdering af de forskellige former for stil, der kommer til udtryk hos de medvirkende.

Samtlige tre kategorier lægger således op til seerens refleksion og vurdering: "Synes jeg selv, at det er billigt, umagen værd, pænt?" Identifikationsaspektet er for seeren lagt ud i tingenes verden, hvor hhv. smag, funktionalitet og undertiden prisbillighed bliver de centrale vurderingskategorier. Set under ét er hensigten at give behagelige seeroplevelser, hvor det tilstræbes at skabe feel good-stemning (Carlsen \& Frandsen, op.cit., p. 4) karakteriseret ved en nedtoning af dramatiske elementer på den ene side og på den anden side opskrivningen af en atmosfære af velvilje og optimisme blandt de medvirkende, der gang på gang berigtiger, hvor godt og værdifuldt det er at have en etisk reflekteret holdning til egen livsførelse, så alle kan 'føle sig hjemme' i familien. Seerne bliver således ikke oprørte på en provokerende måde, men kan først og fremmest føle sig afslappede og inspirerede, have det godt og hygge sig, mens de ser tv.

\section{Vælg din hverdag!}

Den underliggende præmis for alle tre programkategorier er, at hverdagen både kan og bør kvalificeres. Nytte- og makeover-programmer er mest eksplicitte, idet det konkret demonstreres, hvad der fungerer bedst ud fra valgte kriterier. Billige og 'smarte' løsninger tilstræbes ofte i Det' Leth-programmernes håndværksmæssige tips samt i makeoverprogrammer som Helt solgt!, men derudover ligger, som en seermæssig konsensus, en række uudtalte forestillinger til grund for programmerne, f.eks. en genbrugs- eller $\emptyset$ kologisk bevidsthed. Gay Hawkins illustrerer ved hjælp af madprogrammer, hvordan der gennemgående manifesterer sig en diskurs:

About fresh is best, about the importance of home cooking over prepackaged, commodified meals, about the disappearance of certain endangered ingredients. Cooking is being linked with certain modes of living and self-cultivations: learning how to fillet a fish, or scramble an egg is not just a lifestyle matter, it is about the production of a particular habitus: an arrangement of personal habits, attitudes and rituals that are informed by ethical values and principles: cooking for yourself and your family is being valued here, is being classified as good and, by implication, buying takeaway is bad. (Hawkins, 2001, p. 417)

Hverdagen eksponeres derfor altid som et spørgsmål om personligt ansvar og valg af hverdag, hvorved livsstilselementet aktualiseres til fordel for blot den ensformige 
hverdag, hvor valg kan opleves som forudgivne. Programmerne befordrer oplevelsen af et lystfyldt nærvær, hvor nærværet ikke alene betyder tilstedeværelse, "det betyder også relevans og nærhed i forhold til virkeligheden, uden dog at ligne den så meget, at den bliver genkendelig som stedet hvor ulysten, kedsomheden og konflikterne hersker" (Andersen, 1981, p. 46). Programmerne kan opleves som underholdende, fordi de forener "en nærhed til virkeligheden [...] med en distance til bevidstheden om den" (ibid.). Eller man kunne også sige, at de tilbyder et simuleret virkelighedsrum, hvor det er muligt at reflektere over 'det gode liv' og forskellene mellem egen og andres praksis, og hvor selve denne simulation åbner for både emotionelle anknytninger og legende udspil i forhold til evt. egen 'kunnen'. Programmerne handler derfor ikke kun om den faktiske hverdag, men også om abstraktionen: den forestillede hverdag, hvor der nok tages afsæt i en hverdagsvirkelighed, men med fokus konsekvent lagt på det forjættende moment i muligheden for forandring. De mulige valg er det afgørende, hvorved programmerne skaber et rum for seerens drømme og visioner.

Grundlaget for denne type refleksion er forståelsen af identitet som en slags 'DoIt-Yourself-identitet', hvor hverdagslivet ses som "a therapeutic self-help 'project', while entreprising individuals are exhorted to 'empower' themselves by finding better and smarter ways of living" (Lewis, 2007, p. 2). Dette 'empowered' aktør-perspektiv på hverdagen giver programmerne et skær af det ekstraordinære, fordi det tilskriver aktiviteterne en både større og særlig betydning. For seeren kan denne energiske og lystfyldte tilgang til hverdagen smitte, fordi den tilskriver hverdagslivet mening.

Programmerne fremstiller den positive version af, at 'vi er alle forskellige og specielle'. Afgørende for seerens positive stemning er derfor, at de medvirkende oplever sig selv som positivt motiverede for 'det gode liv'. Trods pointeringen af, at vi alle er forskellige, er de fleste programmers deltagere, deres smag og særegenheder dog sjældent noget, der rækker afgørende ud over det ordinære. Deltagerne illustrerer nemlig, hvordan bestræbelsen på forskellighed oftest 'kun' er anstrengelsen værd på et niveau, der handler om livsstilsforskelle, der kan omsættes i et forbrug, afstemt i forhold til en gennemsnitlig middelklasseindkomst og -mode, og at den omvendt aldrig skal udtrykke en så radikal forskellighed, at de færreste seere vil kunne relatere sig til den i et vist omfang - hvilket er et succeskriterium for denne slags feel good-programmer. Det sker selvfølgelig, at forskellen bliver markant, f.eks. i tilfældet med programserierne Feinschmecker og Liebhaverne, men seeren tilbydes da rollen som den, der nysgerrigt måbende følger 'de riges' mulighed for ekstravagance eller som den, der kun kan have bitter latter tilovers for personer, der bevæger sig i denne 'overfladiske' verden af luksus.

\section{Livsstil som public service}

Argumentet er altså, at der ud over læringens konkrete og håndværksmæssige indhold ligger et mere overordnet vidensprojekt nedsunket i livsstilsprogrammer. De handler netop ikke kun om f.eks. at lære seeren at lave diverse madretter. De 'opdyrker' samt positiverer og naturaliserer, at selve det at lave bestemte former for mad på bestemte måder i bestemte situationer er udtryk for både etisk reflekterede ('det gode liv') og smags- og livsstilsorienterede valg. Programmerne handler om smagsdifferentiering, der i lige så høj grad artikuleres omkring som under f.eks. selve den konkrete madlavning. De handler ikke mindst om, at det kan være sjovt og lystfyldt at lave mad, bl.a. fordi 'bør'aspektet tendentielt fylder mindre. De er argumenter for, at eksempelvis madlavning er en livsstil. 
Set i et sådant bredt vidensperspektiv ligger livsstilsprogrammerne derfor programhistorisk i forlængelse af det traditionelle public service-fjernsyns oplysningsvirksomhed, der går tilbage til dansk fjernsyns barndom i 1950'erne. Frem til 1990'erne, hvor konkurrencen blev mærkbar fra især TV 2, havde DR en åbenlys kulturpolitisk dagsorden, hvor, kort sagt, ideen med at se tv skulle være, at seeren på den ene side gerne måtte lære noget og blive klogere af at se tv. På den anden side skulle den viden, seeren tilegnede sig, ikke have instrumentel karakter, men fungere oplysende, kulturelt dannende og være underholdende. Tv's rolle skulle ideelt set være at fungere som et fælles, offentligt forum, der på én og samme tid kunne bidrage til højnelse af det generelle vidensniveau i samfundet og fremme en generel kulturel modernisering af Danmark.

Nogle vil hævde, at dette oplysningsideal er blevet fastholdt frem til i dag, afspejlet i programsætningen af de mange programmer om livsstil. Sammenlignet med tidligere er der dog tale om, at denne programflades sigte først og fremmest er underholdende, og det strategiske argument herfor udspringer af den konkurrence, der præger dansk public service-tv, hvor markedsorienteringen afgør, at jagten på flest mulige seere og skrækken for at støde dem fra sig bliver den afgørende parameter i programlægningen.

Livsstils-boom'et på tv inden for de seneste ti år er et eksempel på, hvordan tv med faktuelle underholdningsprogrammer har populariseret sendefladen ved bl.a. at forvandle 'borgeren' til det 'almindelige menneske' og til forbruger ved at give ham/hende en plads på skærmen som 'betydningsfuld' og 'empowered' aktør i kraft af private, hverdagslige sysler i bestræbelsen på 'det gode liv', men uden den hensigt, som dokumentar-traditionen er kendt for, nemlig den nuancerede og ofte provokerende skildring af mennesker og hverdagsliv. En sådan intention er ikke karakteristisk for livsstils-tv, da programmerne uden provokerende undertoner først og fremmest skal imødekomme seerne på en behagelig måde, så de med inspiration fra programmernes 'almindelige' og 'menneskelige' aktører kan arbejde videre på 'det gode liv' på hjemlig basis. Hverdagslivet optræder derfor primært inden for den diskursive ramme, der udgøres af begrebet 'livsstil' - dvs. at tilværelsesspørgsmål angående 'det gode liv' her giver mening, for så vidt som de forstås i forhold til omsorgsfuld selv-pleje, artikulation af smag, stil og status og forbrug.

Det vil derfor være misvisende at tale om, at livsstils-tvvaretager en dannelsesfunktion, for det første fordi dannelsesbegrebet næppe kan rumme et så instrumentelt videnstilegnelsesaspekt som det, der tendentielt er på spil i mange af disse programmer. Man skulle i så fald omdefinere dannelsesbegrebet, men det er en diskussion, der i denne sammenhæng vil føre for vidt. For det andet er der tale om tv, der, baseret på modens forandringslogik (Christensen, 1991), ser det som sin opgave at opdatere seerne og servicere dem som forbrugere. Som Deborah Philips udtrykker det: "If public broadcasting once saw its role as educative, that education has here become an instruction manual in the appropriate purchase and application of commodities for the home" (Philips, 2005, p. 226). Man kan sige, at tv's oplysningsfunktion med disse programmer er blevet suppleret med en opdateringslogik, der er defineret ved den konstante forandring, samtidig med at dannelse er blevet suppleret af manualen og den praktiske forbrugerguide, hvis logik er efterlevelsen og imitationen.

Livsstils-tv er behagelige, bekræftende og hyggelige tv-programmer, der fungerer som et effektivt redskab for udbredelsen af den opfattelse, at nyttig og nødvendig viden for borgeren i dag er forankret i viden knyttet til rollen som forbruger. Således kan programmerne betragtes som instrumentelle i forhold til realiseringen af de økonomiske potentialer, der, med Bourdieus termer, altid ligger i kim i den kulturelle kapital. 
Ligeledes kan man sige, at livsstilsprogrammerne, deres underholdende kvaliteter ufortalte, medvirker til den udvikling, som Jansson karakteriserer på flg. måde, hvor "the expressivity of social actors is increasingly intertwined with economic activity, embedded in consumption. So while the economy gets culturalized, cultural life gets commercialized" (Jansson, 2002b, p. 6).

Hvor tv tidligere ønskede at oplyse seerne og tog underholdningen til hjælp, da underholdes seerne i dag ved hjælp af distribution af viden om smags- og forbrugsmæssigt passende adfærd. Tv er med til at stimulere behovet for den viden, som man for det første mener, seeren gerne vil have, nemlig en viden om nye ting og tendenser, det er muligt at erhverve sig og skabe forandring ved hjælp af, viden om disse tings sociale og kulturelle værdi og betydning og ikke mindst viden om, "hvordan de pågældende produkter bruges på en rigtig og passende måde" (Bell \& Hollows, 2005, p. 8). For det andet, og som følge heraf, stimulerer tv præcis behovet efter netop disse programmer, som man via raffinerede segmenteringsmodeller har fundet frem til kan bekræfte lige præcis denne type af seere bedst muligt. Derfor kan man, som Lewis, konkludere, at "television adopts a mode of pedagogy that is at once less apparent and more pervasive than earlier public service modes of education" (Lewis, op.cit., p. 8).

At den viden, som sådanne programmer byder på, kan efterspørges som både nødvendig og underholdende af den moderne tv-forbruger, skyldes ikke mindst, at programmerne iscenesætter denne type videnstilegnelse som både lystfyldte oplevelser, der motiverer til refleksion over egen praksis og tilværelse, og som en underholdende leg, hvormed der ikke er forbundet forpligtelse eller anstrengelse. Således stimulerer de vidensperspektivets såvel kognitive og kropsligt forankrede kompetenceaspekt som livsstilsbegrebets imaginative muligheder i relation til dagdrømme, længsler og ønsket om den forjættende forandring. De befinder sig på et niveau, der bedst kan sammenlignes med konsumptionens nydelsesmættede univers. Her fremstår nemlig også 'valget' som afgørende, hvorved der åbnes for stimulering af en utopisk sensibilitet, der, ved anknytning til etisk reflekterede overvejelser om 'det gode liv', er forbundet med de forjættende muligheder i altid nye valg.

\section{Referencer:}

Andersen, M.B. (1981). Underholdning: En alvorlig sag! In F. Mortensen, J. Poulsen \& P. Sepstrup (Eds.), Underholdning i tv. København: Nyt Nordisk Forlag.

Beck, U. (1992). Risk Society. Towards a new modernity. London: Sage.

Bell, D. \& Hollows, J. (2005). Making sense of ordinary lifestyles. In D. Bell \& J. Hollows (Eds.), Ordinary Lifestyles. Popular Media, Consumption and Taste. Berkshire: Open University Press.

Bourdieu, P. (1984 (1979)). Distinction. A Social Critique of the Judgement of Taste. London: Harvard University Press \& Routledge.

Brunsdon, C. (2003). Lifestyling Britain: The 8-9 Slot on British Television. International Journal of Cultural Studies, 6(1), 5-23.

Carlsen, J. \& Frandsen, K. (2005). Nytte- og livsstilsprogrammer på dansk tv. Arbejdspapir 133 fra Center for Kulturforskning. Århus: Aarhus Universitet.

Christensen, C.L. (1991). Smag, stil og mode. Om påklædning og identitet. In H. Fink \& H. Hauge (Eds.), Identiteter i forandring. Kulturstudier 12. Århus: Aarhus Universitetsforlag.

Christensen, C.L. (2007). Viden og ekspertise - itv's livsstilsprogrammer. Arbejdspapir 1. Vidensformidling og offentlighed. København: Institut for Medier, Erkendelse og Formidling, Københavns Universitet.

Christensen, C.L. (2008). 'Det gode liv' - livsstilsprogrammer på dansk tv. In H. Illeris \& H. Christensen (Eds.), Visuel kultur - viden, liv, politik. København: Multivers (under review).

Dyer, R. (1992). Only Entertainment. London: Routledge. 
Ellis, J. (2000). Seeing Things: Television in the Age of Uncertainty. London: I. B. Tauris.

Giddens, A. (1991). Modernity and Self-Identity: self and society in the late modern age. London: Polity Press.

Hawkins, G. (2001). The Ethics of Television. International Journal of Cultural Studies, 4(4), 412-26. London: Sage.

Hill, A. (2005). Reality tv. Audiences and popular factual television. London: Routledge.

Hill, A. (2007). Restyling Factual TV. Audiences and news, documentary and reality genres. London: Routledge.

Hjarvard, S. (2003). Det selskabelige samfund. København: Samfundslitteratur.

Jansson, A. (2002a). Spatial Phantasmagoria. The Mediatization of Tourism Experience. European Journal of Communication, 17(4), 429-443.

Jansson, A. (2002b). The Mediatization of Consumption: towards an analytical framework of image culture. Journal of Consumer Culture, 2(1), 5-31.

Jerslev, A. (2008). Cosmetic Surgery and Mediated Body Theatre: The Designable Body in the Makeover Program The Swan. New Review of Film and Television, 6(3) (in print).

Lewis, T. (2007). 'He Needs to Face his Fears With these Five Queers!': Queer for the Straight Guy, Makeover TV, and the Lifestyle Expert. Television and New Media, 8(4), 285-311.

Medhurst, A. (1999). Day for Night. Sight and Sound, 9(6).

Meyrowitz, J. (1986). No Sense of Place. Oxford \& New York: Oxford University Press.

Moseley, R. (2000). Makeover Takeover on British Television. Screen, 41(3), 299-314.

Philips, D. (2005). Transformation scenes. The television interior makeover. International Journal of Cultural Studies, 8(2), 213-229.

Prokop, U. (1978). Kvindelig livssammenhæng. Om strategiernes indskrænkethed og de umådelige ønsker. Kongerslev: GMT.

Thøgersen, U. (2004). Krop og fænomenologi. Århus: Systime.

Vorderer, P., Steen, F.F. \& Chan, E. (2006). Motivation. In J. Bryant \& P. Vorderer (Eds.), Psychology of Entertainment. London: Routledge. 